\title{
Lessons for the law of armed conflict from commitments of armed groups: identification of legitimate targets and prisoners of war
}

\section{Sandesh Sivakumaran*}

Sandesh Sivakumaran is a lecturer at the School of Law, University of Nottingham.

\begin{abstract}
Armed groups frequently issue ad hoc commitments that contain a law of armed conflict component. These commitments detail the obligation of the relevant armed group to abide by international humanitarian law, the Geneva Conventions, or particular rules set out in the commitment. They commit the group to abide by international standards, sometimes exceed international standards, or in certain respects violate international standards. Although these commitments are often overlooked, they offer certain lessons for the law of armed conflict. This article considers the commitments of armed groups with respect to two specific areas of the law that are either of contested interpretation or seemingly inapplicable to noninternational armed conflicts, namely the identification of legitimate targets and the prisoners of war regime.
\end{abstract}

* I am grateful to the British Academy for a research grant that allowed me to obtain some of the commitments of armed groups and other armed group practice that are mentioned in this article. Thanks are also due to Olivier Bangerter who generously shared with me his own collection of armed group commitments. 
The law of armed conflict forms part of public international law. Accordingly, the materials that comprise the core of public international law - treaties, custom, and judicial decisions - also comprise the core of the law of armed conflict. For these reasons, when reference is made to the law of armed conflict, the materials that instinctively spring to mind include the 1949 Geneva Conventions and 1977 Additional Protocols, the Customary International Humanitarian Law study concluded under the auspices of the International Committee of the Red Cross (ICRC), ${ }^{1}$ and the jurisprudence of the International Criminal Tribunal for the former Yugoslavia (ICTY). Likewise, in both public international law and the law of armed conflict, the actors that are the most prominent in terms of the creation and development of the law are states and state-empowered bodies such as international courts and tribunals. ${ }^{2}$

Yet, in non-international armed conflicts in particular, a whole host of other materials purport to regulate the conflict, some of which emanate from armed groups. These materials frequently have a law of armed conflict component, containing as they do explicit or implicit reference to concepts associated with international humanitarian law (IHL) or international human rights law. Alternatively, they may concern related issues, such as the environment or internally displaced persons. These materials tend to be overlooked as they emanate from nonstate actors and do not comprise part of the fabric of international law. They may also prove difficult to locate. Nonetheless, their potential importance cannot be overstated. They provide an indication as to the views of armed groups on humanitarian norms and they comprise a useful entry point for engaging with armed groups on humanitarian issues. The mere existence of these materials does not, of course, mean that the groups that issue them will comply with the law. Commitments and compliance are linked, but the former does not always lead to the latter. Nonetheless, commitments of armed groups do constitute a further means by which the law of armed conflict may be implemented and enforced.

This article analyses the substance of armed groups' commitments from the perspective of the law of armed conflict. It sets out a typology of commitments of armed groups and considers instances in which the commitments are consistent with the standards set by the law of armed conflict and instances in which they depart from that law. Departure from existing standards includes instances in which commitments fall short of required standards as well as instances in which commitments go above and beyond required standards. The latter are particularly instructive in light of a certain view that exists, namely that armed groups are (only) violators of the law. The article then turns to two particular areas: identification of legitimate targets and prisoner of war status and treatment. The first is controversial in its interpretation, while the second does not apply to non-international armed conflicts as a matter of law. Accordingly, both these subjects constitute a useful lens

1 Jean-Marie Henckaerts and Louise Doswald-Beck, Customary International Humanitarian Law, 2 vols, ICRC/Cambridge University Press, Cambridge, 2005.

2 See generally, Anthea Roberts and Sandesh Sivakumaran, 'Law-making by non-state actors: engaging armed groups in the creation of international humanitarian law', in Yale Journal of International Law, Vol. 37 (forthcoming). 
through which to explore the commitments of armed groups. In relation to the former, the views of armed groups provide an additional perspective on the debate; with regard to the latter, their views indicate that, in particular instances, the commitment may be in advance of the law.

\section{A typology of commitments}

The commitments of armed groups can be loosely divided into four categories: unilateral declarations, ad hoc agreements, codes of conduct and internal regulations, and legislation. To these four categories, three others can be added, namely responses to reports of fact-finding missions, press releases and ad hoc statements, and expressions of motivations for taking up arms. ${ }^{3}$ Although the latter three categories do not constitute commitments as such, they remain important for ascertaining the views of armed groups and engaging with them on humanitarian norms.

\section{Commitments}

\section{Unilateral declarations}

Unilateral declarations usually take the form of commitments to abide by international humanitarian law, the Geneva Conventions, or other specific rules. ${ }^{4}$ One set of unilateral commitments that take a more or less standard form are the Deeds of Commitment on anti-personnel mines concluded under the auspices of Geneva Call. ${ }^{5}$ Unilateral declarations are issued more frequently on an ad hoc basis. For example, the Kurdistan Workers' Party (PKK) stated:

In its conflict with the Turkish state forces, the PKK undertakes to respect the Geneva Conventions of 1949 and the First Protocol of 1977 regarding the conduct of hostilities and the protection of the victims of war and to treat those obligations as having the force of law within its own forces and the areas within its control. ${ }^{6}$

Unilateral declarations may also be issued in relation to particular norms. For example, the Justice and Equality Movement (JEM) and Sudan Liberation Movement-Unity (SLM-Unity), both of Darfur, committed to specific norms of international humanitarian law:

We will do our utmost to guarantee the protection of civilian populations in accordance with the principles of human rights and international humanitarian

3 This part develops the discussion in Sandesh Sivakumaran, 'Re-envisaging the international law of internal armed conflict', in European Journal of International Law, Vol. 22, 2011, pp. 261-262.

4 See below, 'Equivalence with the law of armed conflict'.

5 On Geneva Call, see http://www.genevacall.org/ (last visited 27 September 2011).

6 'PKK Statement to the United Nations', 24 January 1995. 
law. In collaboration with UNICEF, we will adopt measures ensuring protection of children in Darfur. We also affirm the principles of freedom of movement.

We reaffirm our commitment to refrain from targeting or forcibly displacing civilian populations, destroying civilian infrastructure, recruiting children for military operations, and to hold to account perpetrators of acts of rape and other forms of gender based violence. We recognize that placing military assets and personnel in close proximity to civilian areas increases the risk that civilians will be caught up in hostilities or even targeted. We will therefore continue our policy of maintaining a proper physical separation between our armed forces and the civilian population. We also continue to commit to curtailing the militarization of IDP/refugee camps.

We reaffirm our commitment to clearly instructing our personnel on the ground regarding their obligations under human rights and international humanitarian law. ${ }^{7}$

Unilateral declarations of adherence to Additional Protocol I purportedly pursuant to Article 96(3) of that Protocol have also been issued. ${ }^{8}$

\section{Ad hoc agreements}

Bilateral agreements are not infrequently concluded between armed groups and states with which those armed groups are in conflict. These agreements may relate to the law of armed conflict or to specific issues of that law. Such ad hoc agreements include special agreements envisaged by Common Article 3, which calls upon parties to the conflict 'to bring into force, by means of special agreements, all or part of the other provisions of the [particular] Convention', but are broader than such agreements alone. They include agreements on human rights, such as the San José Agreement between the Government of El Salvador and the Frente Farabundo Martí para la Liberación Nacional (FMLN), ${ }^{9}$ as well as ceasefire and peace agreements that contain a law of armed conflict component. Ad hoc agreements are also concluded between armed groups and UN entities or humanitarian agencies, usually on issues relating to humanitarian assistance. ${ }^{10}$ Tripartite agreements are concluded on occasion, between the state, the non-state armed group, and a UN entity. ${ }^{11}$

7 'Statement by the Opposition Movements [JEM and SLM-Unity]', undated (published on 11 July 2008), available at: http://www.hdcentre.org/projects/sudan (last visited 27 September 2011).

8 See e.g. National Democratic Front of the Philippines, 'Declaration of Undertaking to Apply the Geneva Conventions of 1949 and Protocol I of 1977', addressed to the Swiss Federal Council, 5 July 1996; National Democratic Front of the Philippines, 'Declaration of Undertaking to Apply the Geneva Conventions of 1949 and Protocol I of 1977', addressed to the ICRC, 5 July 1996.

9 'Agreement on Human Rights', annexed to UN Doc. A/44/971-S/21541, 16 August 1990.

10 See e.g. Sudan People's Liberation Movement-United/Operation Lifeline Sudan, 'Agreement on ground rules', May 1996.

11 See e.g. 'Memorandum of Understanding between the Government of Sudan, the Sudan Peoples Liberation Movement and the United Nations regarding United Nations Mine Action Support to Sudan', 19 September 2002. 


\section{Codes of conduct and internal regulations}

Just as states draw up military manuals, non-state armed groups draw up codes of conduct. ${ }^{12}$ These codes of conduct, along with other internal regulations, regulate the behaviour of members of the group in their relations both with other members and with persons external to the group. Codes of conduct and internal regulations do not relate solely to issues of the law of armed conflict. Indeed, some codes and regulations do not relate to the law of armed conflict at all. ${ }^{13}$ Others do so implicitly, containing rules that have an equivalent in the law. ${ }^{14}$ Perhaps the classic codes of conduct and internal regulations are those of the Chinese People's Liberation Army (CPLA) issued by Mao Tse Tung originally in 1928. The CPLA's Three Main Rules of Discipline and Eight Points of Attention have been adopted by several unrelated armed groups in the period since they were issued, including the Revolutionary United Front (RUF) of Sierra Leone, the National Democratic Front of the Philippines (NDFP), and the National Resistance Army (NRA) of Uganda. ${ }^{15}$ The Taliban of Afghanistan has also issued a code of conduct, most recently in 2010. ${ }^{16}$

\section{Legislation}

Again, just as states enact legislation, so too do armed groups. The state in which the conflict is taking place will probably challenge the characterization of the materials as 'legislation' and will contest its binding nature. Nonetheless, for the armed group and for individuals living in territory under its control, this legislation will prove important. Legislation is enacted particularly by armed groups that exercise control over territory or which constitute de facto states. Such groups tend to have detailed penal codes that apply to the territory under their control. ${ }^{17}$ Other groups enact constitutions or issue other sorts of legislation..$^{18}$ As with codes of conduct, much of this material fails to refer to the law of armed conflict by name, but much concerns concepts that are the subject of the law of armed conflict. Other legislation does refer to matters of the law of armed conflict by name or concerns human rights issues or the protection of displaced persons. ${ }^{19}$ Legislation differs from codes of conduct and

12 See e.g. in this issue, 'Collection of codes of conduct for armed groups'.

13 See e.g. Kosovo Liberation Army, Interim Regulations on the Organization of Internal Affairs in the Army, Prishtina, 1998.

14 See below, 'Equivalence with the law of armed conflict'.

15 Special Court for Sierra Leone (SCSL), Prosecutor v. Sesay, Kallon and Gbao, Case No. SCSL-04-15-T, Judgment (Trial Chamber), 2 March 2009, para. 705; 'Basic rules of the New People's Army', Principle IV, Point 3, reproduced in National Democratic Front of the Philippines (NDFP), Declaration of Undertaking to Apply the Geneva Conventions of 1949 and Protocol I of 1977, NDFP Human Rights Monitoring Committee Booklet No. 6, pp. 85-90; NRA Code of Conduct, reproduced in Ori Amaza, Museveni's Long March from Guerrilla to Statesman, Fountain Publishers, Kampala, 1998, Appendix 3.

16 Reproduced and translated as an annex to Muhammad Munir, 'The Layha for the Mujahideen: an analysis of the code of conduct for the Taliban fighters under Islamic law', in International Review of the Red Cross, Vol. 93, No. 881, 2011, pp. 103-120.

17 See e.g. Communist Party of Nepal-Maoist, 'Public Legal Code 2060 (2003/2004)'.

18 See e.g. Liberation Tigers of Tamil Eelam, 'Tamil Eelam Child Protection Act' (Act No. 3 of 2006).

19 See e.g. Ejército Zapatista de Liberación Nacional, 'Revolutionary Women's Law'. 
internal regulations in that it is enacted in order to regulate the conduct of persons residing in the area in question, rather than governing the behaviour of members of the armed group alone.

Each of these forms of commitment is considered rare, exceptional, and unlikely to be issued. However, the practice reveals an altogether different picture. One of the unfortunate points is that these commitments tend to be difficult to find, not least because of the lack of a centralized repository for them.

\section{Other important materials}

Three further categories of material are important, even though they do not always consist of commitments in the formal legal sense of the term. These materials give an indication of the views of armed groups on the law and may set out the group's position on a particular point. Accordingly, they remain important.

\section{Responses to reports of fact-finding missions}

Armed groups sometimes respond to reports of UN Special Rapporteurs or reports of human rights organizations, challenging particular facts or interpretations of the law. ${ }^{20}$ They should be encouraged to enter into conversations with the relevant body, particularly where the response does not take the form of an outright and unreasoned denial. This creates points of entry within the group for discussion on related norms and aids increased knowledge on their part.

\section{Press releases and ad hoc statements}

Many non-state armed groups maintain websites. These contain, inter alia, press releases and other statements setting out the position of the groups on various issues relating to the law of armed conflict. Unilateral declarations and commitments may also be found on the groups' websites. Ad hoc statements on the law may also be issued through other organizations. ${ }^{21}$

\section{Expressions of motivations for taking up arms}

Armed groups may also set out the reason as to why they have taken up arms. Not infrequently such reasons include human rights violations taking place in the state in question and ongoing discrimination. Accordingly, following on from these explanations, it is not at all unusual for armed groups to state that the future state will respect human rights and international law. For example, during the 2011

20 See e.g. NDFP, Letter to UN Secretary-General Ban Ki Moon on children in armed conflict, 24 November 2008; 'KNU [Karen National Union] Press Statement on Report of UNSG', 27 April 2009; 'Report of the Panel of Experts established pursuant to Resolution 1591 (2005) concerning the Sudan Issued 2 October 2009: A Response from JEM [Justice and Equality Movement]', 16 November 2009.

21 See e.g. 'Statement of the Opposition Movements [JEM and Sudan Liberation Movement-Unity (SLM-Unity)]', above note 7 . 
violence in Libya, the National Transitional Council issued a statement in which it provided that:

The interim national council will be guided by the following in our continuing march to freedom, through espousing the principles of political democracy. We recognise without reservation our obligation to:

8. Build a democratic Libya whose international and regional relationships will be based upon:

a. The embodiment of democratic values and institutions which respects its neighbours, builds partnerships and recognises the independence and sovereignty of other nations. The state will also seek to enhance regional integration and international co-operation through its participation with members of the international community in achieving international peace and security.

b. A state which will uphold the values of international justice, citizenship, the respect of international humanitarian law and human rights declarations, as well as condemning authoritarian and despotic regimes. The interests and rights of foreign nationals and companies will be protected. Immigration, residency and citizenship will be managed by government institutions, respecting the principles and rights of political asylum and public liberties.

c. A state which will join the international community in rejecting and denouncing racism, discrimination and terrorism while strongly supporting peace, democracy and freedom. ${ }^{22}$

These expressions of motivations constitute important 'hooks' on which to engage the armed group. For example, if an armed group commits violations of the law, it could usefully be reminded of the reason why it is fighting, namely to stand up against violations in the first place.

\section{Commitments of armed groups}

Having set out the various forms that commitments of armed groups take, the next section considers how such commitments compare with the standards imposed by the law of armed conflict.

\section{Equivalence with the law of armed conflict}

Many commitments of armed groups reference IHL, the law of armed conflict, the Geneva Conventions, or specific rules, by name. These commitments, whether unilateral declarations, bilateral agreements, or of a different form, are necessarily equivalent to that which is required by the law, given that they act as a renvoi to the 
law. Commitments of this sort have been made by many an armed group. For example, in 1988, the Liberation Tigers of Tamil Eelam (LTTE), which fought against the Government of Sri Lanka, indicated that it had 'transmitted our notice of acceptance of the Geneva Conventions I-IV of 1949 and the Protocols Additional I and II to the Geneva Conventions to United Nations Headquarters and to the International Committee of the Red Cross'. ${ }^{23}$ In 1991, the NDFP 'declare[d] its adherence to international humanitarian law, especially Article 3 common to the Geneva Conventions as well as Protocol II additional to said conventions, in the conduct of the armed conflict in the Philippines'. ${ }^{24}$ Most recently, during the 2011 armed conflict in Libya, the National Transitional Council declared that it 'would like to reiterate that its policies strictly adhere to the "Geneva Convention relative to the treatment of Prisoners of War"'.25

Commitments to respect international law are also contained in bilateral agreements concluded between warring parties. The Abidjan Peace Agreement between the Government of Sierra Leone and the Revolutionary United Front (RUF) provides a useful example of this tendency. That agreement provided that ' $[\mathrm{t}]$ he Parties undertake to respect the principles and rules of international humanitarian law' ${ }^{26}$ Such commitments may prove important should the peace agreement fail, as was the case with the Abidjan peace agreement itself, or should fighting recommence following the conclusion of a ceasefire agreement. The RUF would later draw on this aspect of the Agreement, commenting that both the Government and the RUF 'had committed themselves to ... full respect for human rights and humanitarian laws'. ${ }^{27}$

Other declarations are less concrete, but still refer to the law of armed conflict. For example, in 1980, the União Nacional para a Independência Total de Angola (UNITA) declared that it 'renews its commitment to the Geneva Conventions and subscribes to the fundamental rules of international law applicable in armed conflicts'. ${ }^{28}$ Quite which rules UNITA was committing to abide by is unclear, given the lack of formal category of the 'fundamental rules of international law applicable in armed conflicts'. Nevertheless, the commitment acts as a renvoi to international law.

These types of commitments are useful in light of their exact equivalence to the law. The armed group commits to exactly what it is that the law requires through a renvoi to the law. However, very real disadvantages are also inherent. When the

23 Letter from Vellupillai Prabhakaran, Leader, Liberation Tigers of Tamil Eelam, to Members and Observers, United Nations Commission on Human Rights, Forty-fourth session, 24 February 1988. See also Letter from Velummylum Manoharan, Representative, LTTE International Secretariat, to Honourable Judges of the US Court of Appeal District of Colombia Circuit (undated), reproduced in the Sunday Times (Sri Lanka), 16 November 1997.

24 NDFP 'Declaration of adherence to international humanitarian law', 15 August 1991, reproduced in NDFP, above note 15, Annex D, p. 98.

25 National Transitional Council, 'The treatment of detainees and prisoners', 25 March 2011.

26 Abidjan Peace Agreement, 30 November 1996, Article 21. See also the Preamble to the Agreement.

27 'Lasting peace in Sierra Leone: the Revolutionary United Front Sierra Leone (RUF/SL) perspective and vision', undated.

28 Declaration by UNITA, 25 July 1980, reproduced in International Review of the Red Cross, Vol. 20, No. 219,1980 , p. 320 . 
armed group commits to abiding by 'international humanitarian law', it may not be familiar with the content of 'international humanitarian law'. It may not be aware that it includes the Geneva Conventions and Additional Protocols, various weapons treaties, rules relating to cultural property, and so forth. Furthermore, the armed group may not have the capacity to abide by all the rules of IHL even if it were willing to do so. ${ }^{29}$

Accordingly, there are advantages in armed groups committing to the substance of particular rules rather than simply referring to the legal terminology used to describe those rules. Commitments to the substance of particular rules may prove more beneficial given that all parties concerned have a clear understanding as to the nature and content of a particular commitment. These commitments may be equivalent to that contained in the law of armed conflict, albeit expressed in a different manner. For example, the 2010 Layha for the Mujahideen provides that ' $\mathrm{t}$ ] he persons responsible in the provinces and districts, squad leaders and all other Mujahids should take maximum measures to avoid deaths and injuries among common people, as well as the loss of their vehicles and other properties'. ${ }^{30}$ This is akin to the IHL obligation to take all feasible precautions. ${ }^{31}$ The CPLA's Three Main Rules of Discipline provided: '[d]on't take a single needle or piece of thread from the masses', while its Eight Points of Attention contained the following injunctions: '[d]on't hit or swear at people', '[d]on't damage crops', '[d]on't take liberties with women', and '[d]on't ill-treat captives'. ${ }^{32}$ The parallels between these injunctions and obligations laid down by international humanitarian law - the principle of humane treatment, and the prohibitions on inhuman treatment, outrages upon personal dignity, pillage, and sexual violence - are evident.

\section{Beyond the law of armed conflict}

The 'substance approach' also suffers from certain disadvantages. When commitments of armed groups do not refer to particular categories of rules, along the lines set out above, but describe the conduct that is prohibited, there is a danger that the commitment may depart from existing standards. This is not inherently a bad thing, for in such instances, the commitment of the armed group may go above and beyond existing standards, offering greater protection to civilians and other persons and entities caught up in the conflict than does the law of armed conflict.

For example, a 2009 agreement between the Government of the Philippines and the Moro Islamic Liberation Front (MILF) commits the parties to 'avoid[ing] acts that would cause collateral damage to civilians'. ${ }^{33}$ This goes beyond the

29 See Marco Sassòli, 'Taking armed groups seriously: ways to improve their compliance with international humanitarian law', in Journal of International Humanitarian Legal Studies, Vol. 1, 2010, p. 32.

30 Layha for the Mujahideen, 2010, above note 16, Rule 65.

31 Additional Protocol I, Art. 57; J.-M. Henckaerts and L. Doswald-Beck, above note 1, Vol. I, Rule 15.

32 See, for analysis, He Xiaodong, 'The Chinese humanitarian heritage and the dissemination and of and education in international humanitarian law in the Chinese People's Liberation Army', in International Review of the Red Cross, Vol. 83, No. 841, 2001, pp. 141-153.

33 'Agreement on the Civilian Protection Component of the International Monitoring Team', 27 October 2009, Art. 1(a). 
requirement of international humanitarian law, which, in its rule on disproportionate attacks, balances the expected injury to civilians and damage to civilian objects with the concrete and direct military advantage anticipated, and prohibits only such attacks in which the former would be 'excessive'. ${ }^{34}$ Another area in which the Government of the Philippines and the MILF have committed to standards beyond that required by the existing law is the commitment of the parties to 'safely return evacuees to their place of origin, provide all the necessary financial/material and technical assistance to start a new life, as well as allow them to be awarded reparations for their properties lost or destroyed by reason of the conflict'. ${ }^{35}$ This provision should be compared with the relevant rules of customary international law, which relate more narrowly to the right to return and to the respect for the property of displaced persons. ${ }^{36}$

Armed groups may also prove 'ahead of the curve', committing to act or not to act in a particular manner, such actions being required by international law only at a later point in time. For example, the NDFP has indicated that it prohibited the recruitment of children under the age of 18 years into its armed forces 'since 1988, ahead of the Convention on the Rights of the Child'. It has also noted that its position in this regard 'is far more advanced than the standard set by the Geneva Conventions'. ${ }^{37}$ It will be recalled that common Article 3 is silent on the question of the recruitment of children into armed forces or armed groups, while Additional Protocol II adopts the standard of 15 years of age. ${ }^{38}$ In respect of a different area of the law, in 1995, the RUF 'appeal[ed] to the United Nations Security Council to seize itself of the grave matter of the spread of small arms and the planting of anti-personnel mines'. It noted that ' $[t]$ he constant use of heavy artillery and cluster bombs ha[s] devastated the countryside'. ${ }^{39}$ It would take until 2008 for a Convention on Cluster Munitions to be adopted, while, at the time of writing, the conventional regulation of small arms remains under consideration. Also in the realm of weapons, in 1988, the FMLN indicated it was abiding by the Mines Protocol to the Convention on Certain Conventional Weapons, setting out the situations in which it was using mines and the associated precautions it was taking. ${ }^{40}$ Yet, at the time in question, the Protocol was limited to international armed conflicts alone, its scope of application being extended to non-international armed conflicts only in 1996.

It may be said that commitments of armed groups are political in nature, used as a tactic in the conflict, or made to enhance their reputation, all without any intention of complying with them. With respect to certain commitments made by certain groups, this may well be true. For example, the call on the part of the RUF to

34 Additional Protocol I, Art. 51(5)(b); J.-M. Henckaerts and L. Doswald-Beck, above note 1, Vol. I, Rule 14.

35 'Agreement on Peace between the Government of the Republic of the Philippines and the Moro Islamic Liberation Front', 22 June 2001, Art. B3.

36 Cf. J.-M. Henckaerts and L. Doswald-Beck, above note 1, Vol. I, Rules 132 and 133.

37 NDFP, NDFP's Defense of the Rights of the Filipino Child, Publication of the NDFP Human Rights Monitoring Committee, 2005, p. 9.

38 Additional Protocol II, Art. 4(3)(c).

39 'Footpaths to democracy: toward a new Sierra Leone', 1995.

40 FMLN, The Legitimacy of Our Methods of Struggle, Inkworks Press, Berkeley, 1988, pp. 10-14. 
regulate small arms and cluster munitions was probably made just as much for tactical reasons as it was for concern over the environment. Furthermore, despite the commitments to respect IHL on the part of the RUF and the LTTE, violations of that law were commonplace. ${ }^{41}$ However, the fact that parties to conflicts make commitments for a variety of reasons is as true for states as it is for armed groups. ${ }^{42}$ Furthermore, the fact that certain commitments may be made for disingenuous reasons cannot be used to tarnish all commitments. Accordingly, commitments of armed groups remain important.

\section{Below the law of armed conflict}

This is not to suggest that commitments of armed groups invariably meet, or exceed, international standards. In respect of certain norms, commitments fall below existing standards and this is a very real danger with the 'substance approach'. The following examples usefully illustrate the point.

The 2010 Layha for the Mujahideen provides:

11. In case of the capture of contractors who transport and supply fuel, equipment or other materials for the infidels and their slave administration, as well as those who build military centres for them and those high- and low-ranking employees of security companies, interpreters of the infidels and drivers involved in enemy supply [business], if a judge proves the fact that the aforementioned persons are indeed involved in such activities, they should be punished by death. If the judge has not been appointed yet in a province it is up to the person responsible in the province to decide the fate [of a person] with regard to the issues of proof and execution.

12. If a military infidel has been captured, his execution, release through prisoner exchange, intentional release or release upon payment in case the Muslims need money, is at the discretion of the Imam and Najib Imam. No one else has the authority to make this decision. If the captive becomes Muslim, the Imam or Najib Imam has the authority to release him in a prisoner exchange, provided that there will be no danger of his becoming an infidel again. ${ }^{43}$

These provisions clearly depart from international humanitarian law, in particular the principle of humane treatment, and the rules relating to the treatment of detainees. ${ }^{44}$

41 See e.g. SCSL, Prosecutor v. Sesay, Kallon and Gbao, above note 15; Report of the Secretary-General's Panel of Experts on Accountability in Sri Lanka, 31 March 2011.

42 See Olivier Bangerter, 'Disseminating and implementing international humanitarian law within organized armed groups: measures armed groups can take to improve respect for international humanitarian law', in International Institute of Humanitarian Law, Non-state Actors and International Humanitarian Law: Organized Armed Groups: A Challenge for the Twenty-first Century, FrancoAngeli, Milano, 2010, pp. 187, 192, and 196.

43 Layha for the Mujahideen, above note 16, Rules 11 and 12.

44 Common Article 3; Additional Protocol II, Arts 4 and 5; Additional Protocol I, Art. 75. 
An associated issue is that of the taking of hostages. It is well known that IHL prohibits the taking of hostages. ${ }^{45}$ For its part, the Ejército de Liberación Nacional (ELN) of Colombia has committed to IHL. ${ }^{46}$ However, it has defined the taking of hostages in such a manner as to allow certain actions that the law of armed conflict would consider to constitute the taking of hostages. Thus, the ELN has stated that it is 'permissible to recover war taxes, and to detain persons who refuse to pay them as a form of pressure in order to obtain payment. These detentions cannot be considered "hostage-taking", because we never use these persons as shields during hostilities'. ${ }^{47}$

\section{Practice in relation to particular norms}

In the two sections that follow, the commitments and practice of armed groups are considered in relation to two areas of the law that are controversial in their interpretation or seemingly inapplicable in their application to non-international armed conflicts, namely the identification of legitimate targets and the prisoners of war regime.

\section{Identification of legitimate targets}

One area in which a considerable divergence of opinion exists is that of the identification of legitimate targets. One of the most fundamental rules of the law of armed conflict is that civilians may not be made the object of attack. ${ }^{48}$ It is accepted that the prohibition on the targeting of civilians does not extend to civilians for such time as they take a direct part in hostilities. ${ }^{49}$ However, there is considerable disagreement as to what this phrase actually means. ${ }^{50}$ Members of the state armed forces are not protected from attack. Greater debate surrounds the question of when members of the armed group may be attacked. ${ }^{51}$ However, even the most restrictive view holds that members of the armed group may be attacked for such time as they take a direct part in hostilities. Several armed groups have expressed their own views on this point, usually taking a position that falls below that of any of the mainstream views of the law of armed conflict. Nonetheless, these views need to be considered.

45 Common Article 3; Additional Protocol II, Art. 4; Additional Protocol I, Art. 75; J.-M. Henckaerts and L. Doswald-Beck, above note 1, Vol. I, Rule 96.

46 See Ejército de Liberación, Declaración sobre el Derecho Internacional Humanitario, 15 July 1995.

47 Nicolás Rodríguez Bautista, Qué es humanizar el conflict colombiano?, 1 May 1996, quoted in Pierre Gassmann, 'Colombia: persuading belligerents to comply with international norms', in Simon Chesterman (ed.), Civilians in War, Lynne Rienner Publishers, London, 2001, p. 73.

48 Additional Protocol I, Art. 51(2); Additional Protocol II, Art. 13; J.-M. Henckaerts and L. Doswald-Beck, Customary International Humanitarian Law, Volume I: Rules, above note 1, Rule 1.

49 Additional Protocol I, Art. 51(3); Additional Protocol II, Art. 13(3).

50 See, in particular, ICRC, 'Interpretive guidance on the notion of direct participation in hostilities under international humanitarian law', in International Review of the Red Cross, Vol. 90, No. 872, 2008, pp. 9911042. But see, for critical views of the ICRC interpretive guidance, the contributions to the symposium in New York University Journal of International Law and Politics, Vol. 42, 2010, pp. 637-769.

51 ICRC, above note 50; New York University Journal of International Law and Politics, above note 50. 
The PKK has indicated that it:

regards the following groups as part of the Turkish security forces and, therefore, as legitimate targets of attack:

- members of the Turkish armed forces;

- members of the Turkish contra-guerrilla forces;

- members of the Turkish Intelligence Service (MIT);

- members of the Turkish gendarmerie;

- village guards.

The PKK does not regard civil servants as members of the security forces, unless they come within one of the above categories. ${ }^{52}$

Along largely similar lines, the NDFP has indicated that it:

regards as legitimate targets of military attack the units, personnel and facilities belonging to the following:

1 The Armed Forces of the Philippines;

2 The Philippine National Police;

3 The paramilitary forces; and

4 The intelligence personnel of the foregoing. ${ }^{53}$

The NDFP has also indicated that '[c]ivil servants of the GRP [Government of the Republic of the Philippines] are not subject to military attack, unless in specific cases they belong to any of the four abovestated categories. ${ }^{54}$

These statements reflect the position of the law of armed conflict in certain respects, considering as they do members of the armed forces and the paramilitary forces to be 'legitimate targets of military attack'. The clarifications surrounding civil servants are useful in light of the fact that, in some conflicts, any representative of the state is considered to be a legitimate target. More difficulty surrounds the gendarmerie or national police. In general terms, members of the police force are considered civilians. ${ }^{55}$ However, in some states, the police may be associated with the armed forces, or may be attached to the armed forces in times of armed conflict. ${ }^{56}$ Accordingly, much will turn on the specificities of the state in question and on the facts. The NDFP's limitation of intelligence personnel to the intelligence personnel of the listed categories is to be welcomed as not considering all intelligence personnel to be legitimate objects of attack. For example, intelligence personnel who are tasked with activities entirely unrelated to the conflict could not be considered legitimate targets of attack, although, in practice, differentiation along these lines may prove difficult. However, the NDFP's limitation is eroded almost

52 'PKK Statement to the United Nations', above note 6.

53 NDFP, 'Declaration of Undertaking', above note 8.

54 Ibid.

55 'Report of the International Commission of Inquiry on Darfur to the United Nations Secretary-General', 25 January 2005, para. 422.

56 See J.-M. Henckaerts and L. Doswald-Beck, above note 1, Vol. I, p. 17. 
entirely with its interpretation of 'intelligence personnel' as including 'casual Government informers, such as peasants who answer when asked by [government] soldiers to identify local CPP [Communist Party of the Philippines] members or someone who calls the police when faced with NPA [New People's Army] extortion'. ${ }^{57}$ This is extremely broad and certainly inconsistent with international standards.

For its part, the Kosovo Liberation Army (KLA) took the view that 'all Serbian forces, whether the police, the military, or armed civilians, are our enemy'. ${ }^{58}$ On the one hand, reference to armed civilians could be taken to mean civilians taking a direct part in hostilities. On the other hand, it could be overly inclusive. Civilians who bear arms to defend themselves, or to prevent looting and the like, would not be considered to be taking a direct part in hostilities. ${ }^{59}$ The ambiguity surrounding certain terms and certain commitments is thus also potentially problematic.

The Sudan People's Liberation Movement/Army (SPLM/A) indicated in 1984 that the following individuals and entities are 'declared enemies of the people and therefore target of the SPLA/SPLM':

a) The incumbent administration of Jaafer Mohammed Nimeiri, its appendages and supporting institutions.

b) Any subsequent reactionary administration that may emerge while the revolutionary war is still being waged.

c) Any individual or group of individuals directly or indirectly cooperating with the autocratic regime in Khartoum in order to sustain or consolidate its rule and to undermine the objectives and efforts of the People's Revolution.

d) Any individual or group of individuals who wage counter-revolutionary war against the SPLA/SPLM or who circulate any subversive literature, verbally or in written form against the SPLA/SPLM with the intent to discredit it or turn public opinion against it.

e) Persons acting as agents or spies for the Sudan Government.

f) Armed bandits that operate to rob ordinary citizens, rape their women or commit any other crime against them, their movable or immovable properties or any other property of the People's revolution.

g) Individuals or groups of people who propagate or advocate ideas, ideologies or philosophies or organize societies and organizations inside the country or abroad, that tend to uphold or perpetuate the oppression of

57 'Report of the Special Rapporteur on Extrajudicial, Summary or Arbitrary Executions, Philip Alston', UN Doc. A/HRC/8/3/Add.2, 16 April 2008, para. 31.

58 Interview with Jakup Krasniqi, spokesman of the Kosovo Liberation Army, published in Koha Ditore, 12 July 1998 (translated from Albanian), Exhibit P00328 in International Criminal Tribunal for the former Yugoslavia (ICTY), Prosecutor v. Haradinaj et al., Case No. IT-04-84-T, Judgment, 3 April 2008.

59 International Criminal Tribunal for Rwanda (ICTR), Prosecutor v. Bagosora et al., Case No. ICTR-98-41T, Judgment and Sentence, 18 December 2008, paras. 2238-9; 'Report of the International Commission of Inquiry on Darfur', above note 55, para. 292. 
the people or their exploitation by the Khartoum regime or by any other system of similar nature. ${ }^{60}$

Just as with the other mentioned armed groups, the SPLM/A considered a much broader section of society to be legitimate targets of attack. In particular, objects of potential attack include 'individuals directly or indirectly cooperating with' the government and persons who advocate ideas that perpetuate the oppression. This widens matters considerably and, again, falls short of international standards.

Despite their considerable variance with the law of armed conflict, these statements remain important because they set out, in concrete terms, the position of groups on the identification of (in their view) legitimate targets. It is revealing that the positions adopted by a number of groups are largely similar, all of which extend the objects that they see as potentially constituting a legitimate target. The statements demonstrate that there is a considerable disparity between what some armed groups consider legitimate targets and who or what the law does not consider the subject of protection. They also indicate that there remains much work to be done in this area of the law.

\section{The prisoners of war regime}

Combatant immunity, by which individuals are not prosecuted 'merely' for taking part in hostilities, and the prisoners of war regime are limited to the law of international armed conflict. No treaty provision applicable to non-international armed conflict mentions either concept. At the Diplomatic Conference of 1949, an attempt to introduce a rule prohibiting prosecution for taking part in a noninternational armed conflict did not succeed. ${ }^{61}$ At the Diplomatic Conference of 1974-1977, a proposal to introduce prisoner of war status into the law of non-international armed conflict similarly failed. ${ }^{62}$ At the level of customary international law, this is one of the few areas of real difference between international and non-international armed conflicts, ${ }^{63}$ and among commentators there is nearunanimity that this is the exclusive domain of the law of international armed conflict. ${ }^{64}$

60 SPLM/A, Penal and Disciplinary Laws, 4 July 1984, Section 29(1)(c), quoted in J.-M. Henckaerts and L. Doswald-Beck, above note 1, Vol. II, pp. 126-127.

61 Final Record of the Diplomatic Conference of Geneva of 1949: Volume II Section B, Federal Political Department, Berne, 1963, p. 44 (Norway), p. 49 (UK), and p. 322 (Norway). For criticism, see Volume II Section B, p. 50 (Burma) and p. 99 (Denmark).

62 Official Records of the Diplomatic Conference on the Reaffirmation and Development of International Humanitarian Law Applicable in Armed Conflicts, Geneva (1974-1977), Volume 5, Federal Political Department, Berne, 1978, p. 91, para. 6 (Norway); Volume 8, p. 359, para. 15 (Sweden); Volume 5, p. 187, paras. 20-21 (Bangladesh). For criticism, see Volume 8, p. 293, para. 41 (Burundi).

63 See J.-M. Henckaerts and L. Doswald-Beck, above note 1, Vol. I, Rules 106-108.

64 See e.g. Yves Sandoz, Christophe Swinarski, and Bruno Zimmerman (eds), Commentary on the Additional Protocols of 8 June 1977 to the Geneva Conventions of 12 August 1949, International Committee of the Red Cross, Geneva, 1987, p. 1332; Waldermar Solf, 'The status of combatants in non-international armed conflicts under domestic law and transnational practice', in American University Law Review, Vol. 33, No. 53, 1983, pp. 57-59; Leslie C. Green, The Contemporary Law of Armed Conflict, Manchester University Press, Manchester, 2000, p. 318; Dieter Fleck, 'The law of non-international armed conflicts', in 


\section{Armed group commitments and practice}

Commitments of armed groups present a more nuanced picture. During the US civil war, a bilateral agreement was concluded between General Dix of the Union forces and General Hill of the Confederate forces, confirming the applicability of the prisoners of war regime to the US civil war, with its detailed provisions on the exchange and release of prisoners of war. ${ }^{65}$ Too much cannot be read into this practice given that it concerned a situation of belligerency. However, during the Spanish civil war, the rebels declared themselves 'ready to observe and respect the Geneva Convention concerning the war wounded, the sick and the prisoners' ${ }^{66}$ Indeed, they went as far as declaring that they 'respect[ed] and caus [ed] to be respected, with the utmost scrupulousness, the laws and customs of warfare'. ${ }^{67}$

Some years later, during the Algerian war of independence, the Front de Libération Nationale (FLN) indicated its willingness to apply the provisions of the Geneva Conventions from an early stage of the conflict. In a letter to the ICRC, dated 23 February 1956, the FLN indicated its willingness to apply the Conventions to all 'prisonniers de guerre français' taken by the FLN 'sous réserve de réciprocité de la part du Gouvernement de la République Française'.68 Throughout the conflict, the FLN insisted 'that it had conferred upon captured French soldiers the status of prisoners of war', ${ }^{69}$ and internal FLN regulations contained detailed rules on the law of war in general and the treatment of prisoners of war in particular. ${ }^{70}$

During the attempted secession of Biafra from Nigeria, the Biafran authorities 'acknowledged, as a minimum, the applicability of the customary law relating to prisoners of war', ${ }^{71}$ and 'assured the ICRC that they were prepared to observe the provisions of the [Geneva] Conventions' ${ }^{72}$ A Declaration of the Biafran authorities 'pledg[ed] to respect civilian populations, give the ICRC facilities for the delivery of humanitarian assistance and organize the exchange of prisoners of

Dieter Fleck (ed.), The Handbook of International Humanitarian Law, Oxford University Press, Oxford, 2008, p. 627.

65 The 'Dix-Hill Cartel' for the General Exchange of Prisoners of War entered into between the Union and Confederate Armies, 22 July 1862, reproduced in H.S. Levie (ed.), Documents on Prisoners of War, International Law Studies, Vol. 60, 1979, p. 34.

66 Frédéric Siordet, 'The Geneva Conventions and civil war', in Revue internationale de la Croix-Rouge, Supplement, Vol. 3, 1950, p. 140.

67 As cited in Norman J. Padelford, International Law and Diplomacy in the Spanish Civil Strife, Macmillan, New York, 1939, p. 597.

68 'Lettre de la délégation algérienne au Caire à David de Traz', 23 février 1956, quoted in Françoise Perret, 'L'action du Comité international de la Croix-Rouge pendant la guerre d'Algérie (1954-1962)', in International Review of the Red Cross, Vol. 86, 2004, p. 926.

69 Arnold Fraleigh, 'The Algerian revolution as a case study in international law', in Richard Falk (ed.), The International Law of Civil War, Johns Hopkins University Press, Baltimore, 1971, p. 196.

70 See Mohammed Bedjaoui, Law and the Algerian Revolution, International Association of Democratic Lawyers, Brussels, 1961, p. 215, n. 17; A. Fraleigh, above note 69, pp. 179 and 196.

71 Allan Rosas, The Legal Status of Prisoners of War, Suomalainen Tiedeakatemia, Helsinki, 1976, p. 196.

72 'External activities', in International Review of the Red Cross, Vol. 7, 1967, p. 536. 
war'. ${ }^{73}$ However, little information is available on the actual treatment of captured soldiers by Biafran entities.

These four situations are by no means exhaustive. Eritrean rebel groups ran 'formally organized prisoner of war camps' during the secession from Ethiopia. ${ }^{74}$ In El Salvador, the FMLN declared that it had 'taken concrete measures to ... guarantee respect for the government troops ... that are under its control as prisoners of war'. It also argued that it 'treat[ed] prisoners of war well even though the Government forces do not do the same' ${ }^{75}$ In Turkey, the PKK indicated that it 'will treat captured members of the Turkish security forces as prisoners of war'. ${ }^{76}$ Most recently, in Libya in 2011, as indicated above, the National Transitional Council declared that it 'would like to reiterate that its policies strictly adhere to the "Geneva Convention relative to the treatment of Prisoners of War". ${ }^{77}$

Thus, despite the absence of provisions on this point in the law of noninternational armed conflict, certain conflicts have seen armed groups declaring that they will treat captured members of the state armed forces as prisoners of war, although the precise extent to which there was compliance with the relevant rules is open to question. This is not infrequently done through a commitment on the part of the armed group to apply the Third Geneva Convention relative to the Treatment of Prisoners of War.

\section{State commitments and practice}

It may be said that members of armed groups would be the primary beneficiaries were the prisoners of war regime to apply to non-international armed conflicts. Accordingly, armed groups will afford treatment as prisoners of war to captured soldiers in the hope that they themselves will be treated as prisoners of war if they are captured. It is thus important to consider the ad hoc commitments of states and state practice on prisoners of war in non-international armed conflicts. Here, too, the position is interesting.

During the US civil war, an order of General Grant provided that '[p]ersons acting as guerrillas without organization and without uniform to distinguish them from private citizens are not entitled to the treatment of prisoners of war when caught, and will not receive such treatment'. ${ }^{78}$ The order, dated 3 July 1862 and predating the Dix-Hill agreement by a few weeks, suggested that those persons acting as part of an army-organized and wearing uniforms - were entitled to treatment as prisoners of war. The Lieber Code of 24 April 1863 confirmed the point, with its numerous detailed rules on prisoners of war. ${ }^{79}$

Cited in Churchill Ewumbue-Monono, 'Respect for international humanitarian law by armed non-state actors in Africa', in International Review of the Red Cross, Vol. 88, No. 864, 2006, p. 907.

74 See Hilaire McCoubrey, International Humanitarian Law, Dartmouth, Aldershot, 1990, p. 175.

75 FMLN, above note 40, pp. 6-7.

76 'PKK Statement to the United Nations', above note 6.

77 National Transitional Council, 'The treatment of detainees and prisoners', 25 March 2011.

78 Official Records of the War of the Rebellion, Series 1, Volume 17, Part 2, p. 69.

79 'Instructions for the government of armies of the United States in the field', 24 April 1863, Section III. 
During the Spanish civil war, the central government committed in a declaration to the ICRC inter alia to co-operate in the setting up of a prisoner of war information agency. ${ }^{80}$ This commitment was made two weeks prior to the commitment of the rebels. The central government later announced that 4,000 prisoners would be 'treated in accordance with the military code providing for the handling of prisoners of war'. ${ }^{81}$

During the Algerian war of independence, France initially tried and executed captured FLN fighters. However, 'on 19 March 1958 General Salan, Commander-in-Chief of the French forces in Algeria, ordered that special camps be set up for NLA [National Liberation Army, the armed wing of the FLN] combatants captured while bearing weapons openly' ${ }^{82}$ France made clear that these individuals were not being considered prisoners of war but their treatment was to be akin to that of prisoners of war. ${ }^{83}$ The relevant order provided that 'the prisoners were to be treated "in as liberal a manner as possible, and that this should be made known". It continued: '[p]roposals for bringing captives before the courts should be systematically avoided, except in the case of those who have committed atrocities or who demonstrate a degree of fanaticism likely to prejudice a favourable evolution in the general state of mind'. ${ }^{84}$ Captured fighters were transferred from the ordinary prisons in which they were housed to these special camps. For some time at least, captured FLN fighters were not prosecuted solely for taking part in the conflict. ${ }^{85}$ A letter from the French military command in Algeria to the French Ministry of Justice dated November 1959 provided that:

les rebelles pris les armes à la main, qui ne sont coupables d'aucun crime terroriste avant leur incorporation dans un groupe rebelle, ne sont pas poursuivis, mais internés dans des camps militaires. Ils sont ainsi assimilés aux membres d'une armée ennemie. ${ }^{86}$

In the view of the ICRC, prisoners detained in these special camps received treatment 'closely related to that of the prisoner-of-war camps'. ${ }^{87}$

80 For the text of the declaration, see F. Siordet, above note 66, pp. 139-140.

81 Norman J. Padelford, 'International law and the Spanish civil war', in American Journal of International Law, Vol. 31, 1937, p. 226, citing a report in the New York Times of 10 August 1936. See also Ann Van Wynen Thomas and A. J. Thomas, 'International legal aspects of the civil war in Spain, 1936-39', in R. Falk, above note 69, p. 122.

82 François Bugnion, 'Jus ad bellum, jus in bello and non-international armed conflicts', in Yearbook of International Humanitarian Law, Vol. 6, pp. 167-198.

83 A. Rosas, above note 71, p. 149.

84 F. Bugnion, above note 82 .

85 A. Fraleigh, above note 69, p. 196; A. Rosas, above note 71, p. 149.

86 Letter of November 1959, quoted in Michel Veuthey, 'La guérilla: le problème du traitement des prisonniers', in Annales d'Études Internationales, Vol. 3, 1972, p. 130. The English text that appears in M. Bedjaoui, above note 70, p. 149, reads in the relevant part: 'rebels captured with guns in their hands, guiltless of any crimes of terrorism before joining a rebel group, are not prosecuted but are interned in military camps. They are treated as members of an enemy army'.

87 ICRC, The ICRC and the Algerian Conflict, ICRC, Geneva, 1962, cited in A. Rosas, above note 71, p. 149. 
During the attempted secession of Biafra, the Federal Government of Nigeria issued an Operational Code of Conduct for the Nigerian Army. This Code included a number of instructions on the conduct of the conflict, including the provision that '[s]oldiers who surrender will not be killed. They are to be disarmed and treated as prisoners of war. They are entitled in all circumstances to humane treatment and respect for their person and their honour'. ${ }^{88}$ Despite the conflict ending with a clear 'winner', the government did not prosecute members of the Biafran forces, instead releasing all captured prisoners. ${ }^{89}$

A more recent example in which the prisoners of war regime was applied took place during the conflicts in the former Yugoslavia. The 22 May 1992 Agreement between representatives of the President of the Republic of BosniaHerzegovina, the President of the Serbian Democratic Party, the President of the Party of Democratic Action, and the President of the Croatian Democratic Community committed the parties to respect and ensure respect for Common Article 3 of the Geneva Conventions and brought into force other provisions of IHL. The provision relating to captured combatants provided that '[c]aptured combatants shall enjoy the treatment provided for by the Third Geneva Convention' relative to the treatment of prisoners of war. ${ }^{90}$

While the practice is certainly not such as to argue that there is a rule of customary international law that requires captured fighters to be granted prisoner of war status, or even to be treated as prisoners of war, the position is more nuanced than the law of non-international armed conflict suggests. States may not be willing to declare in advance, through the law, that they will act in this manner. However, in practice, in certain large-scale non-international armed conflicts, captured fighters have indeed been treated as prisoners of wars or have benefitted from some form of combatant immunity. Much of the practice pre-dates the 'war on terror' and it may be that state classification of the armed groups against which they fight as 'terrorists' will affect the treatment of captured fighters in this regard. In many respects, it is too early to reach a definitive conclusion. However, it is interesting to note that the United Kingdom Manual of the Law of Armed Conflict recommends that, 'while detained in military custody, persons who have taken a direct part in hostilities should be given the same treatment as if they were prisoners of war' and that '[w] herever possible, treatment equivalent to that accorded to prisoners of war should be given'. ${ }^{91}$

88 'Operational Code of Conduct for the Nigerian Army', July 1967, para. 4(e), reproduced in A. H. M. KirkGreene, Crisis and Conflict in Nigeria: A Documentary Sourcebook 1966-1969: Volume I, Oxford University Press, London, 1971, pp. 455-456.

89 'Note from the Nigerian Minister of Defence to the ICRC delegation in Lagos, 14 May 1970, ICRC Archives, file 219 (186); ICRC Annual Report 1970, 10', cited in F. Bugnion, above note 82.

90 Agreement No. 1 of 22 May 1992, para. 2.4, reproduced in Marco Sassòli and Antoine A. Bouvier (eds.), How Does Law Protect in War?, ICRC, Geneva, 2006, p. 1765.

91 UK Ministry of Defence, The Manual of the Law of Armed Conflict, Oxford University Press, Oxford, 2004, pp. 398 and 390. 


\section{Conclusion}

Commitments of armed groups are important. Particularly in light of the fact that armed groups cannot sign and ratify the grand multilateral treaties of the law of armed conflict, commitments provide armed groups with an opportunity to commit to the law. They allow engagement with the armed group on humanitarian norms in general and the norms to which they have committed in particular. Although, in some instances, armed groups may commit to norms that go below existing legal standards, the fact that the position has been set out in advance and in writing means that the international community can engage with them on the required standards. Nonetheless, it may prove difficult to get the group to move away from an existing commitment, even if it falls below international standards. In other instances, armed groups commit to standards that go above and beyond those required by the law of armed conflict, and this is to be welcomed. Commitments of armed groups, and indeed states, can also add nuance to the law. Even in areas in which the law is clear, the practice may suggest that the picture is altogether more complex. The law and practice relating to prisoners of war is one such instance. In sum, ad hoc commitments form a useful addition to the traditional materials of treaties, customary international law, and judicial decisions, and are deserving of greater consideration that is currently afforded to them. 